\title{
Karyotypes of two endemic species of Asterothamnus Novopokr. (Asteraceae) from South Siberia (Tuva)
}

\author{
E. A. Korolyuk ${ }^{1}$, M. N. Lomonosova ${ }^{1}$, T. Eu. Aleshina ${ }^{2}$ \\ ${ }^{1}$ Central Siberian Botanical Garden, Siberian Branch of Russian Academy of Sciences, ul. Zolotodolinskaya, 101, Novosibirsk, \\ 630090, Russia.E-mail: L_Koroljuk@ngsl.ru \\ ${ }^{2}$ The Federal Research Center Institute of Cytology and Genetics, Prospect Lavrentyeva, 10, Novosibirsk, 630090, Russia
}

Key words: Asterothamnus, chromosome number, karyotype.

Summary. The karyotypes of two endemic species such as Asterothamnus heteropappoides and A. poliifolius from South Siberia were studied. Both species were diploids with the chromosome numbers of $2 n=2 x=18$. The polyploidy and satellites were not found. For the first time, the chromosome morphology has been studied and the idiograms have been plotted. The chromosome sizes ranged from 6.42 to $4.23 \mu \mathrm{m}$ for $A$. heteropappoides and the karyotype formula of $8 \mathrm{~m}+1 \mathrm{sm}$ and that from $5.88 \mu \mathrm{m}$ to $3.64 \mu \mathrm{m}$ for A. poliifolius and featuring the karyotype formula of $9 \mathrm{~m}$.

\section{Кариотипы двух эндемичных видов Asterothamnus Novopokr. (Asteraceae) из Южной Сибири (Тува)}

\author{
Е. А. Королюк ${ }^{1}$, М. Н. Ломоносова ${ }^{1}$, Т. Е. Алешина ${ }^{2}$ \\ ${ }^{1}$ Центральный сибирский ботанический сад СО РАН, ул. Золотодолинская, 101, Новосибирск, 630090, Россия \\ ${ }^{2}$ Федеральный исследовательский цееттр институт циитологии и генетики, пр-т Лаврентьева, \\ 10, Новосибирск, 630090, Россия
}

Ключевые слова: Asterothamnus, хромосомные числа, кариотип.

Аннотация. Приведены кариотипы двух эндемичных видов Asterothamnus heteropappoides и A. poliifolius из Южной Сибири. Оба вида диплоидны с числом хромосом $2 n=2 x=18$. Полиплоидии и саттелитов не обнаружено. Впервые изучена морфология хромосом для этих видов и приведены идиограммы. Размер хромосом варьирует от $6.42 \mu \mathrm{m}$ до $4.23 \mu \mathrm{m}$ for $A$. heteropappoides с формулой кариотипа $8 \mathrm{~m}+1 \mathrm{sm}$ и от $5.88 \mu \mathrm{m}$ до 3.64 $\mu \mathrm{m}$ для A. poliifolius с формулой $9 \mathrm{~m}$.

\section{Introduction}

The genus Asterothamnus Novopokr. belongs to the subtribe Asterinae (Cass.) Dumort. (the tribe Astereae, the family Asteraceae). According to Nesom \& Robinson (2007), it includes 13 genera and approximately 270 species. The molecularphylogenetic analysis of the subtribe Asterinae (Li et al., 2012; Korolyuk et al., 2015) states the differentiation of Asiatic taxa into five wellsupported clades. These are the Galatella group with the species of Asian genera Galatella Cass. s. 1. and Tripolium Nees.; the groups of species of North American origin; and three groups of allied Eurasian species: (1) the group of typical Eurasian Aster L. (2) the Heteropappus group including Heteropappus Less. and Kalimeris Cass., as well as (3) Asterothamnus group. The monophyletic 
clade Asterothamnus includes endemic Central Asian species of the genera Asterothamnus and Rhinactinidia Novopokr., several endemic species of Aster from China, and the monotypical genus Arctogeron DC. All the genera mentioned, except for Asterothamnus, contain polyploid taxa. According to the published data, a number of species of the Asteraceae featuring single chromosomes in a chromosome set that may differ morphologically from each other. This can serve as an additional taxonomic marker and reflect evolutionary relations of the allied taxa $(\mathrm{Li}, 2006)$. The species belonging to the Asterothamnus group have been less studied cytologically: the chromosome numbers of $2 n=18$, which have been reported in the two species of Asterothamnus, are known for two species of Asterothamnus (Krasnikov, Korolyuk, 1995) and those for Arctogeron gramineum (L.) DC. (Rostovtzeva, Ligus, 1978). However, the chromosome morphology has not been studied yet.

Asterothamnus includes seven xerophytic species which are restricted to semi-deserts or dry rocky steppes. Most of the species grow in the territories of Mongolia and China; two species are endemic to Middle Asia (Novopokrovskiy, 1950; Grubov, 1982; Chen et al., 2011). Two species occurring in Siberia, A. heteropappoides Novopokr. and A. poliifolius Novopokr., are endemics to Tyva Republic (Korolyuk, 1997).

The aim of this work is to study karyotypic peculiarities of chromosomes of Siberian A. heteropappoides and A. poliifolius as a part of ongoing revision of the genera of the subtribe Asterinae.

\section{Materials and methods}

The plants for the study were collected in the territories of Ovyursky and Tes-Khemsky Regions of the Republic of Tyva. The herbarium samples are stored at the Herbarium of the Central Siberian Botanical Garden SB RAS (NS).

The karyological analysis was made by using root meristem squash preparations from seedlings. Seeds were sprouted in petri dishes on wet sterile sand at $27{ }^{\circ} \mathrm{C}$ and light regime providing 16 hours of daylight and eight hours of darkness. The germs were treated in $0.2 \%$ colchicine for two hours and then fixed in a mixture of ethanol-acetic acid (3:1). The chromosomes were stained with aceto-haematoxyline according to Smirnov (1968). Slides were examined under Axioscop-40 microscope. Chromosome analyses were made on 5-10 slides under 100X magnification. The study of karyotypes and their descriptions were made according to Levan et al. (1964). A1 was estimated according to Romero Zarco (1986), and TF \% followed Huziwara (1962). Chromosomes and chromosome arm lengths measurement were made by MicroMeasure software environment (Aaron Reeves, USA).

\section{Results and discussion}

Morphological peculiarities of chromosomes of two rare species of Asterothamnus from South Siberia were studied.
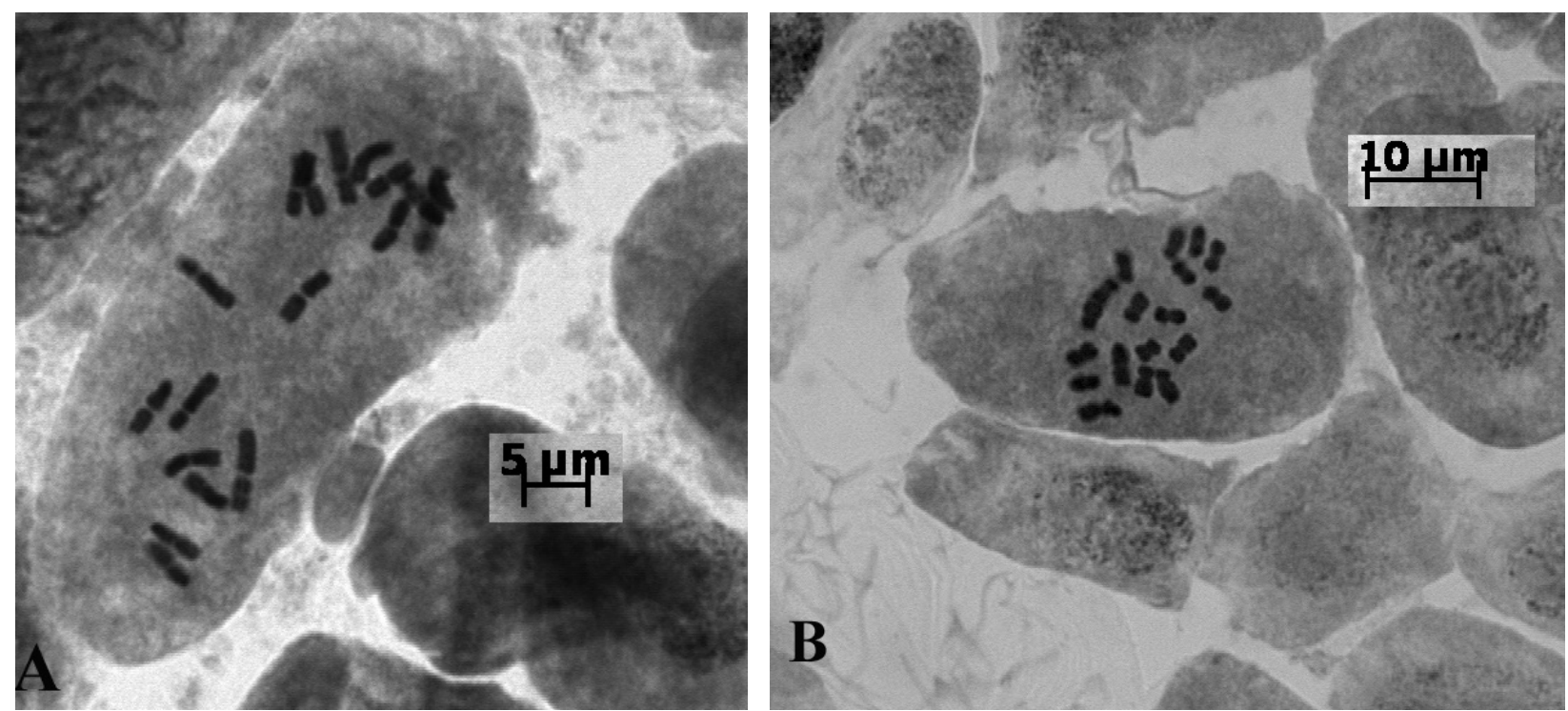

Fig. 1. Microphotograph of somatic metaphases: A - Asterothamnus heteropappoides $(2 n=18)$. Scale bars: $5 \mu$; $\mathrm{B}-$ Asterothamnus poliifolius $(2 n=18)$. Scale bars: $10 \mu \mathrm{m}$. 
Table 1

Parameters of mitotic metaphase chromosomes of Asterothamnus heteropappoides

\begin{tabular}{|c|c|c|c|c|c|c|c|}
\hline $\begin{array}{l}\text { Chro- } \\
\text { mo- } \\
\text { some } \\
\text { no }\end{array}$ & $\begin{array}{l}\text { Total chro- } \\
\text { mosome } \\
\text { length }(\mathrm{C}) \\
\mu \mathrm{m}\end{array}$ & $\begin{array}{l}\text { Long } \\
\text { arm } \\
\text { length } \\
\text { (L) } \mu \mathrm{m}\end{array}$ & $\begin{array}{l}\text { Short } \\
\text { arm } \\
\text { length } \\
\text { (S) } \mu \mathrm{m}\end{array}$ & $\begin{array}{c}\text { Arm } \\
\text { ratio } \\
\mathrm{R}: \mathrm{L} / \mathrm{S} \\
\mu \mathrm{m}\end{array}$ & $\begin{array}{c}\text { Centromeric } \\
\text { index } \\
\text { I: }(\mathrm{S} / \mathrm{C}) . \mathrm{I} 00 \\
\mu \mathrm{m}\end{array}$ & $\begin{array}{c}\text { Relative } \\
\text { size } \\
\text { Mm }\end{array}$ & $\begin{array}{c}\text { Centromeric position } \\
\text { S.D }\end{array}$ \\
\hline 1 & 6.42 & 3.76 & 2.66 & 1.41 & 41.48 & 14.18 & medium \\
\hline 2 & 5.59 & 3.55 & 2.04 & 1.74 & 36.46 & 12.34 & smedium \\
\hline 3 & 5.30 & 3.08 & 2.22 & 1.39 & 41.91 & 11.70 & medium \\
\hline 4 & 5.10 & 2.78 & 2.32 & 1.20 & 45.43 & 11.25 & medium \\
\hline 5 & 4.90 & 2.78 & 2.12 & 1.31 & 43.21 & 10.82 & medium \\
\hline 6 & 4.68 & 2.63 & 2.05 & 1.29 & 43.76 & 10.34 & medium \\
\hline 7 & 4.61 & 2.48 & 2.13 & 1.16 & 46.22 & 10.16 & medium \\
\hline 8 & 4.48 & 2.44 & 2.04 & 1.20 & 45.55 & 9.89 & medium \\
\hline 9 & 4.23 & 2.23 & 2.00 & 1.12 & 47.20 & 9.33 & medium \\
\hline \multicolumn{8}{|c|}{$\mathrm{A} 1=0.23$} \\
\hline & $\mathrm{TF} \%=42$ & & & & & & \\
\hline
\end{tabular}

Table 2

Parameters of mitotic metaphase chromosomes of Asterothamnus poliifolius

\begin{tabular}{|c|c|c|c|c|c|c|c|}
\hline Chromosome no & $\begin{array}{c}\text { Total chromo- } \\
\text { some length } \\
(\mathrm{C}) \mu m\end{array}$ & $\begin{array}{c}\text { Long } \\
\text { arm } \\
\text { length } \\
(\mathrm{L}) \\
\mu m\end{array}$ & $\begin{array}{c}\text { Short } \\
\text { arm } \\
\text { length } \\
(\mathrm{S}) \mu m\end{array}$ & $\begin{array}{c}\text { Arm } \\
\text { ratio } \\
\text { R:L/S }\end{array}$ & $\begin{array}{c}\text { Centromeric } \\
\text { index } \\
\text { I: (S/C).I00 } \\
\mu m\end{array}$ & $\begin{array}{c}\text { Relative } \\
\text { size }\end{array}$ & $\begin{array}{c}\text { Centromeric } \\
\text { position S.D }\end{array}$ \\
\hline 1 & 5.88 & 3.25 & 2.63 & 1.24 & 44.71 & 14.96 & medium \\
\hline 2 & 4.75 & 2.70 & 2.05 & 1.32 & 43.12 & 12.09 & medium \\
\hline 3 & 4.58 & 2.84 & 1.75 & 1.62 & 38.10 & 11.66 & medium \\
\hline 4 & 4.30 & 2.39 & 1.90 & 1.26 & 44.30 & 10.93 & medium \\
\hline 5 & 4.21 & 2.44 & 1.76 & 1.38 & 41.95 & 10.70 & medium \\
\hline 6 & 4.09 & 2.24 & 1.85 & 1.21 & 45.26 & 10.40 & medium \\
\hline 7 & 4.02 & 2.23 & 1.79 & 1.25 & 44.52 & 10.23 & medium \\
\hline 8 & 3.84 & 2.12 & 1.72 & 1.23 & 44.84 & 9.77 & medium \\
\hline 9 & 3.64 & 2.04 & 1.60 & 1.27 & 44.02 & 9.25 & medium \\
\hline & & & & & & \\
\hline & $\mathrm{A} 1=0.23$ & & & & & \\
\hline
\end{tabular}

Asterothamnus heteropappoides Novopokr.; $\mathbf{2 n}=\mathbf{2 x}=\mathbf{1 8}$ (Fig. 1A).

Collection site: "The Republic of Tyva, Ovyursky Region, $3 \mathrm{~km}$ down the Khundurgun Pass towards Khandagaity settlement. Road-side by the Khandagaity River bank, 5073914'N, 92¹7339'E, 05 IX 2013. A. Yu. Korolyuk, E. A. Korolyuk s. n.”

The karyotype consisted of nine pairs chromosomes. The centromeres of the $1^{\text {st }}$ and $3-9^{\text {th }}$ pairs are located at the region $(\mathrm{m})$, while that of the $2^{\text {nd }}$ pairs at the region $(\mathrm{sm})$. Satellites were not visualized. Chromosome sizes ranged from 6.42 to 4.23 $\mu \mathrm{m}$. The longest arm was $3.76 \mu \mathrm{m}$, the shortest arm was $2.00 \mu \mathrm{m}$. Karyotype formula of the species was $2 n=8 \mathrm{~m}+1 \mathrm{sm}$. (Table 1, Fig. 2A). The previously known number of chromosomes determined for the material from Erzinsky Region of Tyva Republic was confirmed (Krasnikov, Korolyuk, 1995).

Asterothamnus poliifolius Novopokr.; $2 n=2 x$ $=\mathbf{1 8}$ (Fig. 1B).

Sampling location: "The Republic of Tyva, Tes-Khemsky Region, east of Ak-Chyraa settlement. The Khoohlu River Valley, pebble alluvium, $50^{\circ} 70480^{\prime} \mathrm{N}, 93^{\circ} 34650^{\prime} \mathrm{E}$, Altitude $=816 \mathrm{~m} .05 \mathrm{IX}$ 2013. A. Yu. Korolyuk, E. A. Korolyuk s. n."

The karyotype consisted of nine pairs of chromosome. Most of the centromeres were situated at the centric region $(\mathrm{m})$. Satellites were not found. Chromosome sizes ranged from 5.88-3.64 $\mu \mathrm{m}$. The longest arm was $3.25 \mu \mathrm{m}$, while the shortest one was $1.6 \mu \mathrm{m}$. Karyotype formula: 9m (Fig. 2B; Table 2). 


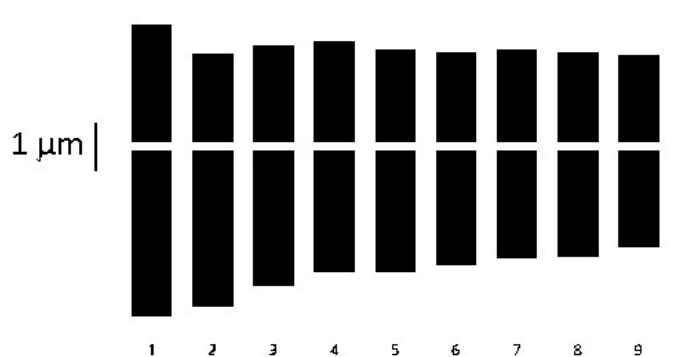

A

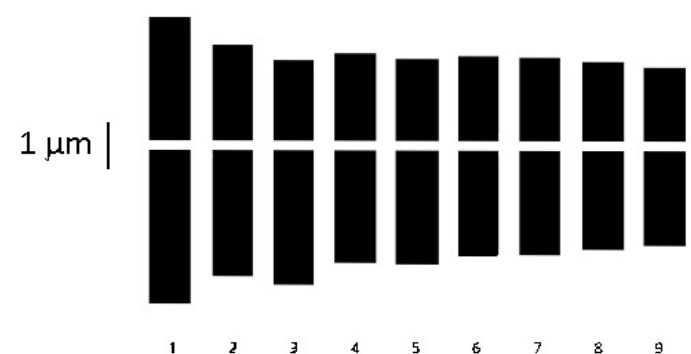

B

Fig. 2. Idiograms: A - of A. heteropappoides, B - of A. poliifolius.

The chromosome number previously determined for the material from O-Shynaah settlement of TesKhemsky Region was confirmed (Krasnikov, Korolyuk, 1995).

Conclusively, the karyotypes of the species studied were similar in chromosome number and size, as well as no satellites and secondary constrictions. Minor differences were revealed for chromosome morphology. Thus, karyotype formula of $A$. heteropappoides was $2 n=18=8 \mathrm{~m}+1 \mathrm{sm}$, while that of A. poliifolius was $9 \mathrm{~m}$.

Acknowledgements. The authors thanks to A. A. Krasnikov for precious advices (Common use centre of CSBG SB RAS). The work was partly supported by RFBR Grant no.13-04-00874.

\section{REFERENCES / ЛИTEPATУPA}

Chen, Y. L., Chen, Y. S., Brouillet, L., Semple, J. C. (2011) Asterea. In: Flora of China. Eds Z. Y. Wu, P. H. Raven, D. Y. Hong. Science Press (Beijing) and Missouri Botanical Garden Press, 20-21: 545-652.

Grubov, V. I. (1982) Opredelitel sosudistykh rasteniy Mongolii [Key to the vascular plants of Mongolia]. Nauka, Leningrad, 433 pp. [In Russian]. (Грубов В. И. Определитель сосудистых растений Монголии. Л.: Наука, 1982. 433 c.)

Huziwara, $\boldsymbol{Y}$. (1962) Karyotype analysis in some genera of Compositae. VIII. Further studies on the chromosome of Aster. Am. J. Bot. 49: 116-119.

Korolyuk, E. A. (1997) Boltonia, Heteropappus, Aster, Kalimeris, Asterothamnus, Rhinactinidia (Krylovia), Arctogeron, Turczaninowia, Galatella, Crinitaria (Linosyris), Tripolium, Brachyactis, Erigeron. In: Flora Sibiri [Flora of Siberia]. Nauka, Novosibirsk, 13: 21-43, engl. transl. 29-53, reg. rev.

Korolyuk, E. A., Makunin, A. I., Matveeva T. (2015) Relationships and generic delimitation of Eurasian genera of the subtribe Asterinae (Astereae, Asteraceae) using molecular phylogeny of ITS. Turk. Journ. Bot. 39: 808-824. DOI: 10.3906/bot-1410-12.

Krasnikov, A. A., Korolyuk, E. A. (1995) Chromosome numbers in some members of the family Asteraceae from Siberian flora. Bot. Zhurn. (Moscow - St. Petersburg) 80(4): 107 [in Russian]. (Красников А. А., Королюк Е. А. Числа хромосом некоторых представителей семейства Asteraceae флоры Сибири // Бот. журн., 1995. Т. 80. № 4. C. 107).

Levan, A., Fredga, K., Sanberg, A. A. (1964) Nomenclature for centromeric position on chromosomes. Hereditas 52: 201-220.

$\boldsymbol{L i}$, W.-P. (2006) Natural hybridization between Aster ageratoides var. scaberulus and Kalimeris indica (Asteraceae): evidence from morphology, karyotype, and ITS sequences. Bot. Studies 47: 191-197.

Li, W.-P., Yang, F. S., Jivkova, T., Yin, G. S. (2012) Phylogenetic relationships and generic delimitation of Eurasian Aster (Asteraceae: Astereae) inferred from ITS, ETS and trnL-F sequence data. Ann Bot-London 109: 1341-1357.

Nesom, G. L., Robinson, H. (2007) Tribe Astereae Cass. In: The families and genera of vascular plants. Flowering plants: Eudicots: Asterales. Eds. J.W. Kadereit, C. Jeffrey. Springer, Berlin, 284-342 pp.

Novopokrovskiy, I. V. (1950) Asterothamnus Novopokr. a new genus from Asteraceae Middel Asian. Notulae Syst ex Herbario Inst Bot nomine Komarovii Acad Sci URSS 13: 330-346 [in Russian]. (Новопокровский И. В. Астеротамнус - Asterothamnus Novopokr., новый род из сем. Сложноцветных из Центральной Азии // Бот. мат. Гербария Бин им. В. Л. Комарова. М.-Л., 1950. Т. 13. С. 330-346).

Romero Zarco, C. (1986) A new method for estimating karyotype asymmetry. Taxon 35: 526-530.

Rostovtzeva, T. S., Ligus, S. A. (1978) Karyological reseach of some species of flora from Siberia. In: Sistematika i geografiya sibirskikh rasteniy [Systematica and geographia of Siberian plants]. Ed. I. M. Krasnoborov. Novosibirsk, 
24-27 pp. [In Russian]. (Ростовцева T. С., Лигус C. A. Кариологическое исследование некоторых видов флоры Сибири // Систематика и география сибирских растений. Под ред. И. М. Красноборова. Новосибирск, 1978. C. 24-27).

Smirnov, Y. A. (1968) Accelerated method for studying somatic chromosomes in fruit trees. Tsitologiya 10: 11321134 [In Russian]. (Смирнов Ю. А. Ускоренный метод исследования соматических хромосом плодовых // Цитология, 1968. Т. 10. С. 1132-1134). 